\title{
Nonlinear Models for Plant Height of Rye Cultivars at Sowing Times
}

\author{
Jéssica Andiara Kleinpaul ${ }^{1}$, Alberto Cargnelutti Filho ${ }^{2}$, Daniela Lixinski Silveira ${ }^{1}$, Ismael Mario Marcio Neu ${ }^{1}$, \\ Cirineu Tolfo Bandeira ${ }^{1} \&$ Andréia Procedi $^{3}$ \\ ${ }^{1}$ Postgraduate Program in Agronomy, Federal University of Santa Maria, Santa Maria, Brazil \\ ${ }^{2}$ Department of Crop Science, Federal University of Santa Maria, Santa Maria, Brazil \\ ${ }^{3}$ Student of Agronomy, Federal University of Santa Maria, Santa Maria, Brazil \\ Correspondence: Alberto Cargnelutti Filho, Department of Crop Science, Federal University of Santa Maria, \\ Avenida Roraima, $\mathrm{n}^{\circ}$ 1000, Bairro Camobi, CEP 97105-900, Santa Maria, RS, Brazil. Tel: 55-55-3220-8899. \\ E-mail: alberto.cargnelutti.filho@gmail.com
}

$\begin{array}{lc}\text { Received: July 25, 2018 } & \text { Accepted: September 1,2018 Online Published: November 15, } 2018 \\ \text { doi:10.5539/jas.v10n12p157 } & \text { URL: https://doi.org/10.5539/jas.v10n12p157 }\end{array}$

\begin{abstract}
Adjusting nonlinear Gompertz and Logistic models will help in the understanding of the growth pattern of the rye crop and also in the height response of the plant, when planted in different environmental conditions. The the aims of this study were to adjust the nonlinear Gompertz and Logistic models for plant height and indicate the one that best describes growth of two rye cultivars in five sowing times. Ten uniformity trials were conducted with the rye crop in the 2016 harvest. In each trial, ten randomly selected plants were evaluated from the first expanded leaf weekly. In each plant height was measured. The adjustment of the Gompertz and Logistic models as a function of the accumulated thermal sum was performed with the average plant height at each evaluation. The parameters $a, b$, and $c$ were estimated for each model. The confidence interval for each parameter and the inflection points, maximum acceleration, maximum deceleration and asymptotic deceleration were calculated. The quality of fit of the models was verified by the coefficient of determination, Akaike's information criterion and residual standard deviation. Intrinsic non-linearity and non-linearity of the parameter effect were quantified. Both models describe satisfactorily the plant height. The model that best describes the growth of rye cultivars is Logistic.
\end{abstract}

Keywords: Secale cereale L., growth models, soil cover plant, winter cereals

\section{Introduction}

Rye (Secale cereale L.) is a winter cereal from the family Poaceae. The crop is efficient both as soil cover and grain production. In Brazil, the rye cultivated area is 3.6 thousand hectares, with a grain productivity of 2,222 $\mathrm{kg}$ $\mathrm{ha}^{-1}$ (CONAB, 2017), being also a potential alternative for crop rotation during winter. It stands out by its hardiness and for playing an important role as cover plant (Doneda et al., 2012). Its initial growth is vigorous, which enables rye to supply early fodder, being a good option as animal forage (Meinerz et al., 2012).

It is important to define cultivars and sowing times that enable the adequate plant growth and development in order to maximize production gains. Therefore, crop growth might be characterized through mathematical modeling, assisting in decision-making along the cycle of a crop (Rosa, Moreira, Rudorff, \& Adami, 2010). Mathematical models are, basically, a simplified description of a mathematical system, elaborated to better understand the functioning of a real system. In this way, the nonlinear models describe growth curves that enable the interpretation of the processes involved in plant growth, since their parameters allow practical interpretation (Sorato, Prado, \& Morais, 2014).

Among the mathematical models that describe plant growth, the nonlinear Gompertz and Logistic models stand out, for being one of the most employed to describe plant behavior based in the observation of the crop itself. The adjustment of these models has been made to evaluate the triticale plants (Karadavut, 2009), the height of maize (Mangueira, Savian, Muniz, Sermarini, \& Crosariol Neto, 2016), the development of cashew (Muianga, Muniz, Nascimento, Fernandes, \& Savian, 2016), the morphological characters of Crotalaria juncea (Bem et al., 2017), the growth of cocoa fruits (Muniz, Nascimento, \& Fernandes, 2017), and the productive features of Crotalaria juncea (Bem et al., 2018). 
The adjustment of growth models for rye plant height is critical for comparing cultivars in different sowing times. The adjustment of the nonlinear Gompertz and Logistic models will help in the understanding of the growth pattern of the rye crop and also in the height response of the plant, when planted in different environmental conditions (sowing times). Therefore, it is expect that the Gompertz and Logistic models will be fitted to plant height and describe successfully the growth of two rye cultivars in five sowing times, allowing the choice of the most adequate model. So, the aims of this study were to adjust the nonlinear Gompertz and Logistic models for plant height and indicate the one that best describes growth of two rye cultivars in five sowing times.

\section{Material and Methods}

Ten uniformity trials were conducted (blank experiments) in a rye crop (Secale cereale L.), in an experimental area in the Department of Crop Science of the Federal University of Santa Maria, Rio Grande do Sul (located at $29^{\circ} 42^{\prime} \mathrm{S}, 53^{\circ} 49^{\prime} \mathrm{W}$, with $95 \mathrm{~m}$ altitude), in 2016. The climate in the region, according to the Köppen climate classification, is Cfa humid subtropical, with hot summers and without a defined dry season (Heldwein, Buriol, \& Streck, 2009) and the soil is classified as dystrophic sandy Red Argisol (Santos et al., 2013).

In these uniformity trials, all the procedures (sowing, fertilization, crop care, and evaluation) were homogeneously performed along the whole experimental area. The seeds of both rye cultivars were sown in five times. Each cultivar in each sowing times represents a uniformity trial. Sowing was conducted in May 3, 2016 (time 1), May 25, 2016 (time 2), June 7, 2016 (time 3), June 22, 2016 (time 4), and July 4, 2016 (time 5), in order to represent the sowing times indicated or not for the crop. In each sowing, the soil was prepared in the conventional way, with light disking, and base fertilization of $25 \mathrm{~kg} \mathrm{ha}^{-1}$ of $\mathrm{N}, 100 \mathrm{~kg} \mathrm{ha}^{-1}$ of $\mathrm{P}_{2} \mathrm{O}_{5}$, and $100 \mathrm{~kg}$ $\mathrm{ha}^{-1}$ of $\mathrm{K}_{2} \mathrm{O}$.

The BRS Progresso and Temprano cultivars were broadcast sown, with a density of 455 seeds $\mathrm{m}^{-2}$. These cultivars were chosen due to their distinct features, namely, the BRS Progresso is intended to grain production and the Temprano is recommended as soil cover and pastureland. In the first sowing time, each cultivar was sown in an area of $320 \mathrm{~m}^{2}(20 \mathrm{~m} \times 16 \mathrm{~m})$. In the other sowing times, each cultivar occupied $375 \mathrm{~m}^{2}(25 \mathrm{~m} \times 15$ $\mathrm{m}$ ). When the plants were between stage 3 and 4 (Large, 1954), an application of $25 \mathrm{~kg}$ of N ha ${ }^{-1}$ was made.

In each uniformity trial, the plants were randomly chosen and the plant height $(\mathrm{PH}$, in $\mathrm{cm})$ was measured with a millimeter ruler (Figure 1). Plant height is the distance from the plant base to the insertion of the flag leaf.

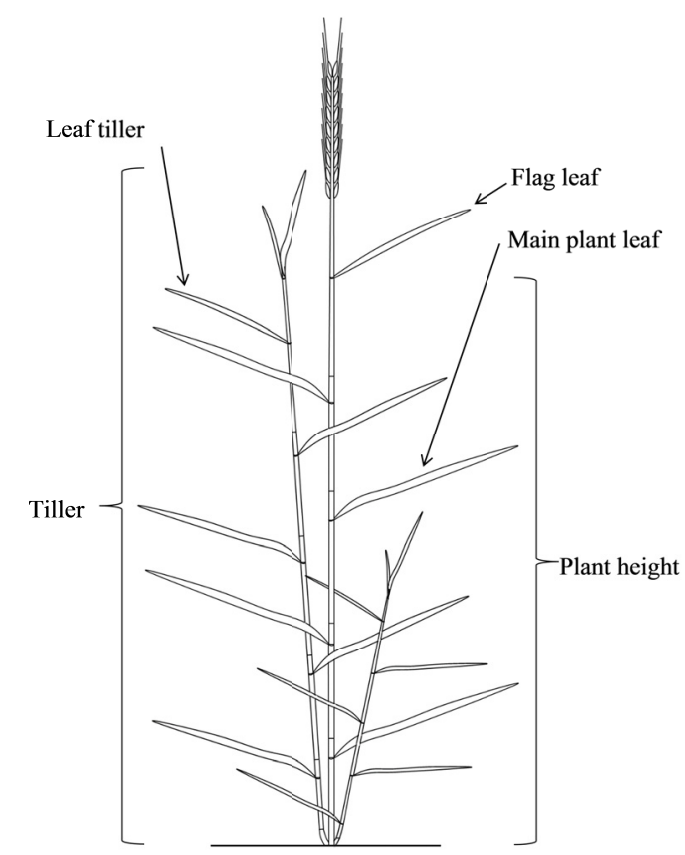

Figure 1. Representation of a rye plant (Secale cereale L.) with indication of how the plant height was measured Source: Authors. 
The evaluations were made in the times between the appearance of the first expanded leaf, stage 1 (Large, 1954) until November 3, 2016 (time 1), October 27, 2016 (time 2), November 10, 2016 (time 3), and November 18, 2016 (times 4 and 5). Altogether, 16, 15, 17, 17, and 15 evaluations were made with the BRS Progresso cultivar in times $1,2,3,4$, and 5, respectively. For the Temprano cultivar 18, 17, 18, 19, and 17 evaluations were made in times $1,2,3,4$ e 5 , respectively.

The minimum and maximum air temperatures in ${ }^{\circ} \mathrm{C}$ were recorded from the sowing time until the end of the evaluation by the Meteorological Station of the Federal University of Santa Maria, located $50 \mathrm{~m}$ from the experimental area. The daily thermal sum was calculated from the minimum and maximum air temperatures (Equation 1) by the Gilmore and Rogers (1958), and Arnold (1960) method,

$$
\mathrm{dTS}=\frac{\operatorname{Tmax}+\mathrm{Tmin}}{2}-\mathrm{Tb}
$$

where, dTS is the daily thermal sum $\left({ }^{\circ} \mathrm{C}\right)$, Tmax é is the daily maximum temperature $\left({ }^{\circ} \mathrm{C}\right)$, Tmin is the minimum daily temperature $\left({ }^{\circ} \mathrm{C}\right)$, and $\mathrm{Tb}$ is the basal temperature for rye, of $0{ }^{\circ} \mathrm{C}$ (Bruckner \& Raymer, 1990). Then, the accumulated thermal sum was calculated (Equation 2),

$$
\text { aTS }=\sum \mathrm{dTS}
$$

where, aTS is the accumulated thermal sum and $\sum \mathrm{dTS}$ is the summation of the daily thermal sum.

For plant height (dependent variable), the nonlinear Gomperz and Logistic models were adjusted according to the accumulated thermal sum (independent variable) in each uniformity trial. The input data for the dependent variable were the averages of the ten plants of each evaluation.

The assumptions of the mathematical models were checked, based on the residues, through the Shapiro-Wilk test for the normality of the residues, the Durbin-Watson test for the presence of autocorrelation of the residues, and the Breusch-Pagan for the homoscedasticity of the residues.

The Gompertz (Windsor, 1932) (Equation 3),

$$
\mathrm{y}=\mathrm{a} \cdot \exp [-\exp (\mathrm{b}-\mathrm{cx})]
$$

and Logistic models were adjusted (Nelder, 1961) (Equation 4),

$$
y=a /[1+\exp (-b-c x)]
$$

where, $\mathrm{y}$ is the dependent variable, $\mathrm{x}$ is the independent variable, $\mathrm{a}$ is the asymptotic value, $\mathrm{b}$ is the ratio between the initial growth value and the final value, and $\mathrm{c}$ is the maximum rate of relative growth.

Were have calculated for the Gompertz model the point of inflection (PI) (Equations 5 and 6),

$$
\begin{aligned}
& x i=\frac{b}{c} \\
& y i=\frac{a}{e}
\end{aligned}
$$

the point of maximum acceleration (PMA) (Equations 7 and 8),

$$
\begin{gathered}
\mathrm{xi}=\frac{\mathrm{b}-\ln \left(\frac{3+\sqrt{5}}{2}\right)}{\mathrm{c}} \\
\mathrm{yi}=\mathrm{a} \cdot \exp \left(-\frac{3+\sqrt{5}}{2}\right)
\end{gathered}
$$

the point of maximum deceleration (PMD) (Equations 9 and 10),

$$
\begin{gathered}
x i=\frac{b-\ln \left(\frac{3-\sqrt{5}}{2}\right)}{c} \\
y i=a \cdot \exp \left(-\frac{3-\sqrt{5}}{2}\right)
\end{gathered}
$$

and the point of asymptotic deceleration (PAD) (Equations 11 and 12),

$$
\begin{gathered}
\mathrm{xi}=\frac{\mathrm{b}-\ln (36.8-9.77 \sqrt{14.06})}{\mathrm{c}} \\
\mathrm{yi}=\mathrm{a} \cdot \exp [-(36.8-9.77 \sqrt{14.06})]
\end{gathered}
$$

where, a b and c are the parameters of the model and e is the base of the Napierian logarithm (Mischan \& Pinho, 2014).

For the Logistic model were calculated the point of inflection (PI) (Equations 13 and 14), 


$$
\begin{aligned}
x i & =\frac{-b}{c} \\
y i & =\frac{a}{2}
\end{aligned}
$$

the point of maximum acceleration (PMA) (Equations 15 and 16),

$$
\begin{gathered}
\mathrm{xi}=\frac{1}{\mathrm{c}}[-\mathrm{b}-\ln (2+\sqrt{3})] \\
\mathrm{yi}=\frac{\mathrm{a}}{3+\sqrt{3}}
\end{gathered}
$$

the point of maximum deceleration (PMD) (Equations 17 and 18)

$$
\begin{gathered}
\mathrm{xi}=\frac{1}{\mathrm{c}}[-\mathrm{b}-\ln (2-\sqrt{3})] \\
\mathrm{yi}=\frac{\mathrm{a}}{3-\sqrt{3}}
\end{gathered}
$$

and the point of asymptotic deceleration (PAD) (Equations 19 and 20),

$$
\begin{gathered}
\mathrm{xi}=\frac{1}{\mathrm{c}}[-\mathrm{b}-\ln (5-2 \sqrt{6})] \\
\mathrm{yi}=\frac{\mathrm{a}}{2(3-\sqrt{6})}
\end{gathered}
$$

where, $a, b$ and $c$ are the parameters of the model (Mischan \& Pinho, 2014).

For each model (Gompertz and Logistic), the estimation of their parameters $(a, b$, or $c$ ) were compared between the cultivars (BRS Progresso versus Temprano) and each sowing time (times 1, 2, 3, 4, and 5), with a total of 30 comparisons (two models $\times$ three estimates of each model $\times$ five sowing times). Then, for each model (Gompertz and Logistic), the estimation of their parameters $(a, b$, or $c)$ were compared between their sowing times ( 1 versus 2, 1 versus 3, 1 versus 4, 1 versus 5, 2 versus 3, 2 versus 4, 2 versus 5,3 versus 4, 3 versus 5 , and 4 versus 5) in each cultivar (BRS Progresso and Temprano), totaling 120 comparisons (two models $\times$ three estimates of each model $\times$ two cultivars $\times 10$ combinations of sowing times).

For these comparisons, were adopted the criterion of confidence interval overlap of the parameters of each model (Gompertz and Logistic). For this, the lower and upper limits of the 95\% confidence interval were calculated. Therefore, for each model (Gompertz and Logistic), were adopted the following criterion to compare the cultivars in each sowing time: if the parameter estimate $(a, b$, or $c)$ for a certain cultivar is between the lower and upper limits of the confidence interval of the parameter of another cultivar, both of the estimates do not differ. The parameter estimates differ, between the cultivars, if no estimate is placed between the lower and upper limits of the confidence interval of the parameter of another cultivar. In the same way, comparing the sowing times in each cultivar, were considered that: if a parameter estimate $(a, b$, or $c)$ for a certain season is within the lower and upper limits of the confidence interval of the parameter of another season, these estimates are not different. The parameter estimates between the sowing times differ when none of the estimates is within the lower and upper limits of the confidence interval of the parameter of another sowing time.

In order to choose the adequate models for plant height, the evaluators of the adjustment quality were determined: coefficient of determination $\left(\mathrm{R}^{2}\right)$ (Equation 21); Akaike information criterion (AIC) (Equation 22); and residual standard deviation (RSD) (Equation 23),

$$
\begin{gathered}
\mathrm{R}^{2}=1-\frac{\mathrm{SQR}}{\mathrm{SQT}} \\
\mathrm{AIC}=\ln \left(\sigma^{2}\right)+2(\mathrm{p}+1) / \mathrm{n} \\
\mathrm{RSD}=\sqrt{\frac{\mathrm{SQR}}{\mathrm{n}-\mathrm{p}}}
\end{gathered}
$$

where, SQR is the sum of the squared residues and SQT is the sum of the total squares, $\ln \left(\sigma^{2}\right)$ is the logarithm of the variance of the errors, $\mathrm{p}$ is the number of parameters of the model and $\mathrm{n}$ is the number of evaluations. A high $\mathrm{R}^{2}$ value is intended for these evaluators of the adjustment quality, since this will represent a better adjustment of the model. In contrast, for AIC and RSD, the lower the value, the better is the adjusted model.

A non-linear model is considered the best, compared to others, when it presents a pattern close to the linear one. In order to analyze the pattern of the models, Ratkowsky (1983) recommends checking the nonlinearity measures of the curves using Bates and Watts (1988), which quantified the nonlinearity found in the models based on the geometrical concept of curvature, and showed that the nonlinearity might be decomposed in 
intrinsic nonlinearity (IN) and the nonlinearity caused by the effect of the parameter (EP). A model should be chosen among others if it presents the lowest values of nonlinearity due both to its intrinsic nonlinearity and to the effect of the parameter.

The statistical analyses were performed using Microsoft Office Excel $^{\circledR}$ and the statistical software R (R Development Core Team, 2018).

\section{Results and Discussion}

The cultivar BRS Progresso presented its maximum plant height values in times 2 and 3, while the Temprano cultivar has shown its maximum values in times 3 and 4 (Table 1). These values were obtained from the average of ten plants in each evaluation. Thus, the cultivars have shown a great performance in the field in these sowing times. That is, the BRS Progresso cultivar had a good development outside (time 2) the time indicated for sowing (time 3), with June and July being the months indicated for cultivars indicated for grain production (Embrapa, 2014). Moreover, the Temprano cultivar, with a sowing time starting in March (Embrapa, 2014), showed its best development in June. This development is related to the lack of big rainfalls, with a predominance of low intensity rain, although in times not so staggered during the period of raising the cultivar, which enabled the most adequate development for the crop (Figure 2).

Table 1. Minimum, mean and maximum plant height $(\mathrm{PH}, \mathrm{cm})$, based on the mean of 10 plants in each evaluation, of cultivars BRS Progresso e Temprano in five sowing times of rye (Secale cereale L.)

\begin{tabular}{lccc}
\hline Time & Minimum & Mean & Maximum \\
\hline BRS Progresso & & & \\
Time 1 (May 3, 2016) & 2.30 & 59.67 & 126.30 \\
Time 2 (May 25, 2016) & 1.80 & 66.21 & 164.20 \\
Time 3 (June 7, 2016) & 1.80 & 70.58 & 169.20 \\
Time 4 (June 22, 2016) & 1.40 & 68.86 & 158.60 \\
Time 5 (July 4, 2016) & 2.30 & 72.47 & 142.60 \\
\hline Temprano & & & \\
Time 1 (May 3, 2016) & 2.40 & 37.00 & 139.20 \\
Time 2 (May 25, 2016) & 1.70 & 31.37 & 139.60 \\
Time 3 (June 7, 2016) & 1.10 & 48.20 & 156.30 \\
Time 4 (June 22, 2016) & 0.90 & 48.59 & 143.40 \\
Time 5 (July 4, 2016) & 1.20 & 54.25 & \\
\hline
\end{tabular}

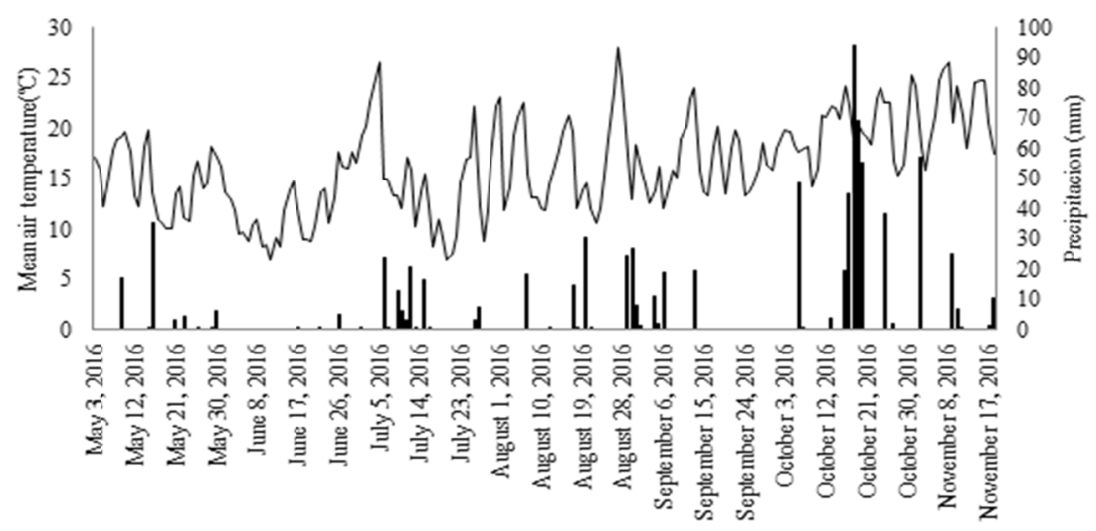

Figure 2. Precipitation $(\mathrm{mm})$ and mean air temperature $\left({ }^{\circ} \mathrm{C}\right)$, of the rye experiment (Secale cereale L.)

For the plant height of the cultivars, in the sowing times, the p-value was higher than 0.05 in the Shapiro-Wilk (SW) normality test, in the Gompertz and Logistic models, indicating that the residues of each model follow the normal distribution. The independence test of Durbin-Watson (DW), for both models, presented a p-value above 0.05 , showing that the residues are independent, that is, are not autocorrelated at a significance level of $5 \%$. And in the homogeneity test of the residues of Breush-Pagan (BP), for both models, the p-value was also higher than 
0.05 , which shows that the residues present a constant variance at a $5 \%$ significance level, for the plant height of the cultivars in the sowing times. So, the assumptions of normality, independence, and homogeneity of the residues were met (Table 2).

Table 2. P-value of the Shapiro-Wilk (SW), Durbin-Watson (DW) and Breusch-Pagan (BP) tests applied on the Gompertz and Logistic model residues for plant height as a function of accumulated thermal sum $\left({ }^{\circ} \mathrm{C}\right)$ of cultivars BRS Progress and Temprano in five sowing times of rye (Secale cereale L.)

\begin{tabular}{|c|c|c|c|c|c|}
\hline \multirow{2}{*}{ Time } & \multirow{2}{*}{ Estatistic } & BRS Progresso & Temprano & BRS Progresso & Temprano \\
\hline & & \multicolumn{2}{|c|}{ Gompertz } & \multicolumn{2}{|c|}{ Logistic } \\
\hline Time 1 & SW & 0.140 & 0.058 & 0.540 & 0.050 \\
\hline \multirow[t]{2}{*}{ May 3, 2016} & DW & 0.278 & 0.504 & 0.486 & 0.616 \\
\hline & $\mathrm{BP}$ & 0.225 & 0.521 & 0.140 & 0.490 \\
\hline Time 2 & SW & 0.066 & 0.994 & 0.366 & 0.152 \\
\hline \multirow[t]{2}{*}{ May 25, 2016} & DW & 0.144 & 0.138 & 0.780 & 0.276 \\
\hline & BP & 0.539 & 0.335 & 0.402 & 0.122 \\
\hline Time 3 & SW & 0.205 & 0.457 & 0.075 & 0.050 \\
\hline \multirow[t]{2}{*}{ June 7, 2016} & DW & 0.930 & 0.172 & 0.638 & 0.362 \\
\hline & $\mathrm{BP}$ & 0.090 & 0.116 & 0.050 & 0.050 \\
\hline Time 4 & SW & 0.271 & 0.271 & 0.052 & 0.744 \\
\hline \multirow[t]{2}{*}{ June 22, 2016} & DW & 0.192 & 0.192 & 0.442 & 0.050 \\
\hline & $\mathrm{BP}$ & 0.300 & 0.300 & 0.234 & 0.489 \\
\hline Time 5 & SW & 0.086 & 0.086 & 0.331 & 0.089 \\
\hline \multirow[t]{2}{*}{ July 4, 2016} & DW & 0.050 & 0.050 & 0.360 & 0.326 \\
\hline & $\mathrm{BP}$ & 0.497 & 0.497 & 0.209 & 0.112 \\
\hline
\end{tabular}

In the work of Muniz et al. (2017), the assumptions of normal distribution, independence, and homogeneity of residues were met for the volume of cocoa fruits in the Gompertz and Logistic models, in the same way that in em Fernandes, Pereira, Muniz, and Savian (2014), the assumptions were met for the accumulation of the fresh pulp of coffee fruits. Therefore, the assumptions for the models of this study were met and the Gompertz and Logistic models are adequate for the adjustment for plant height of the rye cultivars BRS Progresso and Temprano, evaluated in five sowing times.

For each model (Gompertz and Logistic), the parameter estimates $(a, b$, or $c$ ) were compared between the cultivars (BRS Progresso versus Temprano) in each sowing time (times 1, 2, 3, 4, and 5) (Table 3) and between the sowing times ( 1 versus 2, 1 versus 3,1 versus 4,1 versus 5,2 versus 3,2 versus 4,2 versus 5,3 versus 4,3 versus 5, and 4 versus 5) in each cultivar (BRS Progresso and Temprano) (Table 4), through the criterion of confidence interval overlap. 
Table 3. Estimates of the parameters $\left(a, b\right.$ and $c$ ), lower limit $\left(\mathrm{LL}_{2,5 \%}\right)$ and upper limit $\left(\mathrm{UL}_{97,5 \%}\right)$ of the confidence interval $\left(\mathrm{CI}_{95 \%}\right)$ of the Gompertz and Logistic models for plant height as a function of accumulated thermal sum ${ }^{\circ} \mathrm{C}$ ) of cultivars ${ }^{(1)}$ BRS Progress and Temprano in five sowing times of rye (Secale cereale L.)

\begin{tabular}{|c|c|c|c|c|c|c|c|}
\hline \multirow{2}{*}{ Time } & \multirow{2}{*}{ Parameter } & Estimate & $\mathrm{LL}_{2.5 \%}$ & $\mathrm{UL}_{97.5 \%}$ & Estimate & $\mathrm{LL}_{2.5 \%}$ & $\mathrm{UL}_{97.5 \%}$ \\
\hline & & \multicolumn{3}{|c|}{ BRS Progresso } & \multicolumn{3}{|c|}{ Temprano } \\
\hline \multicolumn{8}{|l|}{ Gompertz } \\
\hline Time 1 & $a^{n s}$ & 116.3112 & 110.9945 & 121.6280 & 124.1218 & 109.1728 & 139.0707 \\
\hline \multirow[t]{2}{*}{ May 3, 2016} & $b^{*}$ & 3.4657 & 2.8908 & 4.0406 & 7.6396 & 4.8778 & 10.4013 \\
\hline & $c^{\mathrm{ns}}$ & 0.0038 & 0.0032 & 0.0044 & 0.0050 & 0.0032 & 0.0069 \\
\hline Time 2 & $\mathrm{a}^{*-}$ & 150.3814 & 135.1986 & 165.5641 & 102.4608 & 85.2911 & 119.6305 \\
\hline \multirow[t]{2}{*}{ May 25, 2016} & $b^{*}$ & 2.7986 & 2.1357 & 3.4616 & 10.3026 & 3.7672 & 16.8381 \\
\hline & $\mathrm{c}^{\mathrm{ns}}$ & 0.0031 & 0.0023 & 0.0039 & 0.0073 & 0.0027 & 0.0120 \\
\hline Time 3 & $a^{n s}$ & 131.9025 & 122.4404 & 141.3647 & 135.3721 & 124.8593 & 145.8849 \\
\hline \multirow[t]{2}{*}{ June 7, 2016} & $b^{*}$ & 3.4758 & 2.4438 & 4.5079 & 5.3429 & 3.7751 & 6.9108 \\
\hline & $c^{\mathrm{ns}}$ & 0.0040 & 0.0028 & 0.0052 & 0.0040 & 0.0028 & 0.0052 \\
\hline Time 4 & $a^{\text {ns }}$ & 124.5188 & 114.2665 & 134.7711 & 128.2198 & 118.0222 & 138.4174 \\
\hline \multirow[t]{2}{*}{ June 22, 2016} & $b^{*}$ & 4.4471 & 2.4920 & 6.4023 & 9.0893 & 5.3013 & 12.8772 \\
\hline & $c^{\mathrm{ns}}$ & 0.0053 & 0.0031 & 0.0076 & 0.0066 & 0.0038 & 0.0093 \\
\hline Time 5 & $a^{*^{*}}$ & 125.2007 & 118.7027 & 131.6987 & 115.0514 & 106.2586 & 123.8442 \\
\hline \multirow[t]{2}{*}{ July 4, 2016} & $b^{*}$ & 3.4076 & 2.6244 & 4.1907 & 7.9221 & 4.6416 & 11.2026 \\
\hline & $\mathrm{c}^{\mathrm{ns}}$ & 0.0042 & 0.0033 & 0.0052 & 0.0067 & 0.0039 & 0.0094 \\
\hline \multicolumn{8}{|l|}{ Logistic } \\
\hline Time 1 & $a^{n s}$ & 113.5268 & 108.9470 & 118.1067 & 123.7441 & 111.7260 & 135.7622 \\
\hline \multirow[t]{2}{*}{ May 3, 2016} & $\mathrm{~b}^{*}$ & -5.7793 & -6.5887 & -4.9699 & -10.6636 & -13.3512 & -7.9759 \\
\hline & $c^{\mathrm{ns}}$ & 0.0057 & 0.0048 & 0.0065 & 0.0066 & 0.0049 & 0.0084 \\
\hline Time 2 & $a^{*-}$ & 143.7418 & 134.4917 & 152.9918 & 104.8720 & 89.7693 & 119.9747 \\
\hline \multirow[t]{2}{*}{ May 25, 2016} & $b^{*}$ & -5.1513 & -5.9597 & -4.3429 & -10.4469 & -14.5073 & -6.3864 \\
\hline & $\mathrm{c}^{\mathrm{ns}}$ & 0.0051 & 0.0042 & 0.0060 & 0.0072 & 0.0043 & 0.0101 \\
\hline Time 3 & $\mathrm{a}^{\mathrm{ns}}$ & 129.7035 & 121.4863 & 137.9207 & 133.1832 & 125.3150 & 141.0515 \\
\hline \multirow[t]{2}{*}{ June 7, 2016} & $b^{*}$ & -5.6549 & -7.1023 & -4.2076 & -8.0024 & -9.6676 & -6.3371 \\
\hline & $\mathrm{c}^{\mathrm{ns}}$ & 0.0058 & 0.0043 & 0.0074 & 0.0056 & 0.0044 & 0.0069 \\
\hline Time 4 & $a^{\text {ns }}$ & 124.2929 & 115.5518 & 133.0339 & 128.1100 & 119.9451 & 136.2748 \\
\hline \multirow[t]{2}{*}{ June 22, 2016} & $\mathrm{~b}^{*}$ & -6.6908 & -8.9602 & -4.4214 & -11.7823 & -15.2583 & -8.3064 \\
\hline & $c^{\mathrm{ns}}$ & 0.0073 & 0.0047 & 0.0098 & 0.0081 & 0.0057 & 0.0106 \\
\hline Time 5 & $\mathrm{a}^{*^{-}}$ & 123.6520 & 120.0644 & 127.2395 & 114.3118 & 107.2020 & 121.4216 \\
\hline \multirow[t]{2}{*}{ July 4, 2016} & $\mathrm{~b}^{*}$ & -5.8360 & -6.5921 & -5.0800 & -10.7092 & -14.0612 & -7.3572 \\
\hline & $\mathrm{c}^{\mathrm{ns}}$ & 0.0064 & 0.0056 & 0.0073 & 0.0086 & 0.0058 & 0.0113 \\
\hline
\end{tabular}

Note. ${ }^{(1)}$ Comparison of the estimates of the parameters $(a, b$ and $c)$ among the cultivars: $*$ Estimates differ to $5 \%$ of significance. ${ }^{\text {ns }}$ Not significant. 
Table 4. Comparison of the estimates of the parameters $(a, b$ and $c)$ between sowing times ${ }^{(1)}$ based on the confidence interval $\left(\mathrm{CI}_{95 \%}\right.$ ) of the Gompertz and Logistic models for plant height as a function of the cumulative thermal sum $\left({ }^{\circ} \mathrm{C}\right)$ of cultivars BRS Progress and Temprano in five sowing times of rye (Secale cereale $\mathrm{L}$.)

\begin{tabular}{|c|c|c|c|c|c|}
\hline Time & Time & $\begin{array}{l}\text { Gompertz } \\
\text { BRS Progresso }\end{array}$ & $\begin{array}{l}\text { Gompertz } \\
\text { Temprano }\end{array}$ & $\begin{array}{l}\text { Logistic } \\
\text { BRS Progresso }\end{array}$ & $\begin{array}{l}\text { Logistic } \\
\text { Temprano }\end{array}$ \\
\hline \multicolumn{6}{|l|}{$a$} \\
\hline Time 1 (May 3, 2016) & Time 2 (May 25, 2016) & * & * & $*$ & $*$ \\
\hline Time 1 (May 3, 2016) & Time 3 (June 7, 2016) & $*$ & ns & $*$ & ns \\
\hline Time 1 (May 3, 2016) & Time 4 (June 22, 2016) & ns & ns & * & ns \\
\hline Time 1 (May 3, 2016) & Time 5 (July 4, 2016) & $*$ & ns & $*$ & ns \\
\hline Time 2 (May 25, 2016) & Time 3 (June 7, 2016) & * & $*$ & * & $*$ \\
\hline Time 2 (May 25, 2016) & Time 4 (June 22, 2016) & * & $*$ & $*$ & * \\
\hline Time 2 (May 25, 2016) & Time 5 (July 4, 2016) & * & ns & * & ns \\
\hline Time 3 (June 7, 2016) & Time 4 (June 22, 2016) & ns & ns & ns & ns \\
\hline Time 3 (June 7, 2016) & Time 5 (July 4, 2016) & ns & $*$ & ns & * \\
\hline Time 4 (June 22, 2016) & Time 5 (July 4, 2016) & ns & $*$ & ns & * \\
\hline \multicolumn{6}{|l|}{$b$} \\
\hline Time 1 (May 3, 2016) & Time 2 (May 25, 2016) & * & ns & ns & ns \\
\hline Time 1 (May 3, 2016) & Time 3 (June 7, 2016) & ns & ns & ns & ns \\
\hline Time 1 (May 3, 2016) & Time 4 (June 22, 2016) & ns & ns & ns & ns \\
\hline Time 1 (May 3, 2016) & Time 5 (July 4, 2016) & ns & ns & ns & ns \\
\hline Time 2 (May 25, 2016) & Time 3 (June 7, 2016) & ns & ns & ns & ns \\
\hline Time 2 (May 25, 2016) & Time 4 (June 22, 2016) & ns & ns & ns & ns \\
\hline Time 2 (May 25, 2016) & Time 5 (July 4, 2016) & ns & ns & ns & ns \\
\hline Time 3 (June 7, 2016) & Time 4 (June 22, 2016) & ns & ns & ns & * \\
\hline Time 3 (June 7, 2016) & Time 5 (July 4, 2016) & ns & ns & ns & ns \\
\hline Time 4 (June 22, 2016) & Time 5 (July 4, 2016) & ns & ns & ns & ns \\
\hline \multicolumn{6}{|l|}{$c$} \\
\hline Time 1 (May 3, 2016) & Time 2 (May 25, 2016) & ns & ns & ns & ns \\
\hline Time 1 (May 3, 2016) & Time 3 (June 7, 2016) & ns & ns & ns & ns \\
\hline Time 1 (May 3, 2016) & Time 4 (June 22, 2016) & ns & ns & ns & ns \\
\hline Time 1 (May 3, 2016) & Time 5 (July 4, 2016) & ns & ns & ns & ns \\
\hline Time 2 (May 25, 2016) & Time 3 (June 7, 2016) & ns & ns & ns & ns \\
\hline Time 2 (May 25, 2016) & Time 4 (June 22, 2016) & ns & ns & ns & ns \\
\hline Time 2 (May 25, 2016) & Time 5 (July 4, 2016) & * & ns & $*$ & ns \\
\hline Time 3 (June 7, 2016) & Time 4 (June 22, 2016) & ns & ns & ns & $*$ \\
\hline Time 3 (June 7, 2016) & Time 5 (July 4, 2016) & ns & ns & ns & $*$ \\
\hline Time 4 (June 22, 2016) & Time 5 (July 4, 2016) & ns & ns & ns & ns \\
\hline
\end{tabular}

Note. ${ }^{(1)}$ Comparison of the estimates of the parameters $(a, b$ and $c)$ between sowing times: * Estimates differ to $5 \%$ of significance. ${ }^{\text {ns }}$ Not significant.

For example, comparing the estimate of parameter $a$ of the Gompertz model between the BRS Progresso and Temprano cultivars, in time 1 (May 3, 2016), the following was verified: the estimate of parameter $a(116.3112)$ for the BRS Progresso cultivar is within the confidence interval of the estimate of this parameter (124.1218) for the Temprano cultivar, that is, between its lower (109.1728) and upper (139.0707) limits. It was also verified that the estimate of parameter $a$ (124.1218) for the Temprano cultivar is outside the confidence interval of the estimate of parameter $a$ (116.3112) for the BRS Progresso cultivar, that is, is outside its lower (110.9945) and (121.6280) upper limits. In this example, since at least one estimate of parameter $a$ for a cultivar is within the confidence interval of the other cultivar, it was concluded that the estimate of parameter $a$ (116.3112) for the BRS Progresso cultivar does not differ from the estimate of this parameter (124.1218) for the Temprano cultivar (Table 3). 
In another example, comparing the estimate of parameter $b$ for the Gompertz model between the BRS Progresso and Temprano cultivars, in time 1 (May 3, 2016), the following was verified: the estimate of parameter $b(3.4657)$ for the BRS Progresso cultivar is outside the confidence interval of this parameter (7.6396) for the Temprano cultivar, that is, outside its lower (4.8778) and upper (10.4013) limits. It was also verified that the estimate of parameter $b$ (7.6396) for the Temprano cultivar is outside the confidence interval of this parameter (3.4657) for the BRS Progresso cultivar, that is, is outside its lower (2.8908) and upper (4.0406) limits. Therefore, in this example, since no estimate of parameter $b$ is within the lower and upper limits of the confidence interval of this parameter for the other cultivar, it was concluded that the estimate of parameter $b$ (3.4657) for the BRS Progresso cultivar differs, at a 5\% level of significance, from the estimate of this parameter (7.6396) for the Temprano cultivar (Table 3).

For each model (Gompertz and Logistic), the comparisons of the estimates of their parameters $(a, b$, or $c)$ between the sowing times in each cultivar (Table 4) are interpreted according to the following example: comparing the estimate of parameter $a$ of the Gompertz model between time 1 (May 3, 2016) and time 2 (May 25,2016 ), for the BRS Progresso cultivar, the following was verified: the estimate of parameter $a$ (116.3112) for time 1 is outside the confidence interval of this parameter (150.3814) for time 2, that is, outside its lower (135.1986) and upper (165.5641) limits. It was also verified that the estimate of parameter $a(150.3814)$ for time 2 is outside the confidence interval of the estimate of this parameter (116.3112) for time 1, that is, is outside its lower (110.9945) and upper (121.6280) limits. Therefore, in this example, since no estimate of parameter $a$ is within the lower and upper limits of the confidence interval of parameter $a$ from the other period, it was concluded that the estimate of this parameter (116.3112) for time 1 differs, at a $5 \%$ significance level, from the estimate of parameter $a(150.3814)$ for time 2 (Tables 3 and 4 ).

Comparing the cultivars by the method of confidence interval overlap, the results have shown the same pattern between the estimates of the parameters of the Gompertz and Logistic models (Table 3). That is, comparing the BRS Progresso and Temprano cultivars with the Gompertz and Logistic models in each sowing time can be inferred that their behavior is the same as the asymptote, the ratio between their initial and final growth values, and the maximum rate of relative growth.

Analyzing the estimate of parameter $a$ in the Gompertz and Logistic (Table 3) models there was a difference at a $5 \%$ level of significance between the cultivars for plant height, in times 2 and 5 . This pattern shows that the asymptote or the maximum plant height is different between the rye cultivars in these sowing times, that is, in times 2 and 5, there is a different growing pattern between the BRS Progresso and Temprano cultivars until the maximum height for the culture. For the Gompertz and Logistic models, the estimates of parameter $b$ differ at a $5 \%$ level of significance for plant height between the cultivars in all sowing times. These results show that the growth of BRS Progresso e Temprano cultivars is different, exhibiting different transition moments in their growth rates. It can also be said that the BRS Progresso cultivar presents a higher growth rate in relation to the Temprano cultivar.

Analyzing parameter $c$ for the Gompertz and Logistic models, it can be seen that in all the sowing times the maximum growth rate exhibits the same pattern between the BRS Progresso and Temprano cultivars in the sowing times (Table 3). Therefore, by analyzing the estimates of the parameters can be inferred that both models might be indicated to represent the growth of BRS Progresso and Temprano cultivars since they both present the same pattern of significance for the parameters.

Comparing the estimates of the parameters of the nonlinear models for plant height, between the sowing times in each cultivar, it was verified was no significant effect in the estimates of the parameters in $75.83 \%$ of the comparisons (Table 4). This comparison between the estimates of the parameters was found in a study comparing the sowing times of Crotalaria juncea in the Gompertz and Logistic models (Bem et al., 2018). However, in this study a smaller non-significant effect was observed in the estimates of the parameters in the comparisons between the sowing times. Thus, it can be inferred that for the models that present parameter estimates with a non-significant effect, the use of the model from any sowing time might be adequate since it presents the same growth pattern.

In order to make inferences about the growth of a certain agricultural crop, the points of inflection, maximum acceleration, maximum deceleration, and asymptotic deceleration might be used. So, were might realize that, through the point of inflection that for the Gompertz and Logistic models, the BRS Progresso cultivar needs a smaller thermal sum until the crop reaches $50 \%$ of its growth than the Temprano cultivar in each sowing time (Table 5). Further, comparing both models, in the Gompertz model were might infer that the BRS Progresso and Temprano cultivars reach their maximum growth rates with the least thermal sum, when compared to the growth 
rates of the cultivars in the Logistic model. However, in the Logistic model, since the plants present a higher thermal sum they reach the point of inflection with higher plant heights. Different values for the point of inflection between the cultivars and the progenies might also be observed in the work of Deprá, Lopes, Noal, Reiniger, and Cocco (2016) when they analyzed features from maize cultivars and progenies based on the thermal sum.

Table 5. Coefficient of determination $\left(\mathrm{R}^{2}\right)$, akaike information criterion (AIC) and residual standard deviation (RSD), intrinsic nonlinearity (IN) and the nonlinearity caused by the effect of the parameter (EP), point of inflection (PI), point of maximum acceleration (PMA), point of maximum deceleration (PMD), point of asymptotic deceleration (PAD) of the Gompertz and Logistic models for plant height as a function of the cumulative thermal sum $\left({ }^{\circ} \mathrm{C}\right.$ ) of cultivars BRS Progress and Temprano in five sowing times of rye (Secale cereale L.)

\begin{tabular}{|c|c|c|c|c|c|c|c|c|c|c|c|}
\hline & & $\begin{array}{l}\text { Time } 1 \\
\text { May 3, } \\
2016\end{array}$ & $\begin{array}{l}\text { Time } 2 \\
\text { May } 25, \\
2016\end{array}$ & $\begin{array}{l}\text { Time } 3 \\
\text { June } 6 \text {, } \\
2016\end{array}$ & $\begin{array}{l}\text { Time } 4 \\
\text { June } 22 \text {, } \\
2016\end{array}$ & $\begin{array}{l}\text { Time } 5 \\
\text { July 4, } \\
2016\end{array}$ & $\begin{array}{l}\text { Time } 1 \\
\text { May 3, } \\
2016\end{array}$ & $\begin{array}{l}\text { Time } 2 \\
\text { May 25, } \\
2016\end{array}$ & $\begin{array}{l}\text { Time } 3 \\
\text { June } 6 \text {, } \\
2016\end{array}$ & $\begin{array}{l}\text { Time } 4 \\
\text { June } 22 \text {, } \\
2016\end{array}$ & $\begin{array}{l}\text { Time } 5 \\
\text { July } 4, \\
2016\end{array}$ \\
\hline & & \multicolumn{5}{|c|}{ BRS Progresso } & \multicolumn{5}{|c|}{ Temprano } \\
\hline \multicolumn{12}{|c|}{ Gompertz } \\
\hline $\mathrm{R}^{2}$ & & 0.992 & 0.981 & 0.975 & 0.961 & 0.985 & 0.967 & 0.931 & 0.981 & 0.969 & 0.972 \\
\hline $\mathrm{AIC}$ & & 3.262 & 4.525 & 4.735 & 5.195 & 4.084 & 4.203 & 4.457 & 4.185 & 4.534 & 4.453 \\
\hline RSD & & 4.413 & 8.132 & 9.123 & 11.477 & 6.531 & 8.459 & 10.159 & 7.722 & 9.864 & 8.885 \\
\hline IN & & 0.184 & 0.225 & 0.295 & 0.447 & 0.215 & 0.215 & 0.665 & 0.301 & 0.408 & 0.433 \\
\hline EP & & 0.354 & 0.732 & 0.596 & 0.777 & 0.408 & 0.408 & 1.304 & 0.576 & 0.705 & 0.780 \\
\hline \multirow[t]{2}{*}{ PI } & $\mathrm{x}$ & 914.183 & 892.737 & 864.842 & 832.171 & 804.269 & 1525.640 & 1403.057 & 1321.942 & 1382.116 & 1186.640 \\
\hline & $\mathrm{y}$ & 42.788 & 55.322 & 48.524 & 45.808 & 46.059 & 45.662 & 37.693 & 49.801 & 47.169 & 42.325 \\
\hline \multirow[t]{2}{*}{ PMA } & $\mathrm{x}$ & 660.315 & 585.733 & 625.377 & 652.077 & 577.115 & 1333.442 & 1271.990 & 1083.820 & 1235.770 & 1042.479 \\
\hline & $\mathrm{y}$ & 8.484 & 10.970 & 9.622 & 9.083 & 9.133 & 9.054 & 7.474 & 9.875 & 9.353 & 8.393 \\
\hline \multirow[t]{2}{*}{ PMD } & $\mathrm{x}$ & 1168.052 & 1199.741 & 1104.308 & 1012.264 & 1031.424 & 1717.837 & 1534.124 & 1560.064 & 1528.462 & 1330.800 \\
\hline & $\mathrm{y}$ & 79.385 & 102.638 & 90.026 & 84.986 & 85.452 & 84.715 & 69.931 & 92.394 & 87.512 & 78.525 \\
\hline \multirow[t]{2}{*}{ PAD } & $\mathrm{x}$ & 1388.258 & 1466.037 & 1312.022 & 1168.478 & 1228.458 & 1884.550 & 1647.812 & 1766.611 & 1655.404 & 1455.846 \\
\hline & $\mathrm{y}$ & 98.545 & 127.411 & 111.755 & 105.499 & 106.077 & 105.162 & 86.810 & 114.694 & 108.635 & 97.478 \\
\hline \multicolumn{12}{|c|}{ Logistic } \\
\hline $\mathrm{R}^{2}$ & & 0.992 & 0.989 & 0.977 & 0.969 & 0.995 & 0.976 & 0.950 & 0.986 & 0.979 & 0.979 \\
\hline AIC & & 3.254 & 3.982 & 4.681 & 4.990 & 3.114 & 4.022 & 4.376 & 4.026 & 4.265 & 4.226 \\
\hline RSD & & 4.258 & 6.088 & 8.776 & 10.268 & 3.967 & 7.191 & 8.657 & 6.630 & 8.215 & 7.681 \\
\hline IN & & 0.138 & 0.169 & 0.247 & 0.326 & 0.114 & 0.253 & 0.370 & 0.177 & 0.245 & 0.284 \\
\hline EP & & 0.298 & 0.443 & 0.516 & 0.621 & 0.222 & 0.633 & 0.899 & 0.357 & 0.490 & 0.568 \\
\hline \multirow[t]{2}{*}{ PI } & $\mathrm{x}$ & 1018.485 & 1009.659 & 968.861 & 922.479 & 909.067 & 1613.214 & 1454.386 & 1417.413 & 1445.957 & 1246.477 \\
\hline & $\mathrm{y}$ & 56.763 & 71.871 & 64.852 & 62.146 & 61.826 & 61.872 & 52.436 & 66.592 & 64.055 & 57.156 \\
\hline \multirow[t]{2}{*}{ PMA } & $\mathrm{x}$ & 786.398 & 751.534 & 743.227 & 740.907 & 703.926 & 1413.980 & 1271.042 & 1184.147 & 1284.337 & 1093.192 \\
\hline & $\mathrm{y}$ & 23.991 & 30.376 & 27.410 & 26.266 & 26.131 & 26.150 & 22.162 & 28.145 & 27.073 & 24.157 \\
\hline \multirow[t]{2}{*}{ PMD } & $\mathrm{x}$ & 1250.572 & 1267.783 & 1194.496 & 1104.052 & 1114.208 & 1812.447 & 1637.730 & 1650.678 & 1607.577 & 1399.761 \\
\hline & $\mathrm{y}$ & 89.536 & 113.366 & 102.294 & 98.027 & 97.521 & 97.594 & 82.710 & 105.038 & 101.037 & 90.155 \\
\hline \multirow[t]{2}{*}{ PAD } & $\mathrm{x}$ & 1422.479 & 1458.976 & 1361.623 & 1238.543 & 1266.156 & 1960.020 & 1773.533 & 1823.458 & 1727.290 & 1513.299 \\
\hline & $\mathrm{y}$ & 103.111 & 130.553 & 117.803 & 112.889 & 112.307 & 112.390 & 95.250 & 120.963 & 116.356 & 103.823 \\
\hline
\end{tabular}

With the other points shown (Table 5) there is a pattern in the Gompertz and Logistic models similar to the pattern previously presented. This is due to the fact that the cultivars exhibit different characteristics for production. In this way, since the BRS Progresso cultivar is intended to grain production, it presents a faster development than the Temprano cultivar, which needs to develop mass in order to be promising to be used as soil cover and pastureland, demanding more thermal sum and having a longer crop cycle. So, based on these points, the investigator might choose the best sowing time, opting or not for faster initial growths. He might also predict the moment in which the crop will start to decline in growth, until it reaches the maximum peak, resembling the asymptote of the chosen model. Therefore, according to Bem et al. (2018), the period between the maximum point of acceleration and the end of the point of inflection is the best time to infer about management procedures such as fertilization, pest and disease control, and herbicide application, since in this interval the plant will respond efficiently. However, crop management is necessary along the whole period in which the crop is in the field. 
In order to appoint an adequate model, it should analyze the quality of their adjustments. So, the choice of the best model for each cultivar and sowing time should take into account the $\mathrm{R}^{2}$, AIC, and RSD values. Regarding $\mathrm{R}^{2}$, the higher its value, the better will be the adjustment of the model. In contrast, a better adjustment is found when the AIC and RSD values are smaller. Thus, comparing the models in each combination of cultivar and sowing time the indicators are always favorable to the Logistic model (higher $\mathrm{R}^{2}$ and lower AIC e RSD) (Table 5). In the same way, Karadavut (2009), Muianga et al. (2016), and Muniz, Nascimento, and Fernandes (2017), analyzing the quality of the adjustment of the models, have also found a better quality for the Logistic model.

In order to indicate the nonlinear model that presents the better pattern of the crop, one should appoint the model with the pattern closest to the linear model. In this way, through the intrinsic nonlinearity and the nonlinearity caused by the effect of the parameter it was verified that the Logistic model is indicated for the BRS Progresso and Temprano cultivars since it presents the smallest values, showing that this nonlinear model is closest to the linear one. Analyzing these parameters in the Logistic model, it can be verified that in the BRS Progresso cultivar, time 5 (Table 5, Figure 3) followed by time 1 exhibit the model closest to the linear, while for the Temprano cultivar time 3 (Table 5, Figure 3) presents the best model. In this context, in order to indicate the best models in their studies, Fernandes et al. (2014) evaluated the coffee tree, testing the linear pattern of the models using the same evaluators employed in the present study.
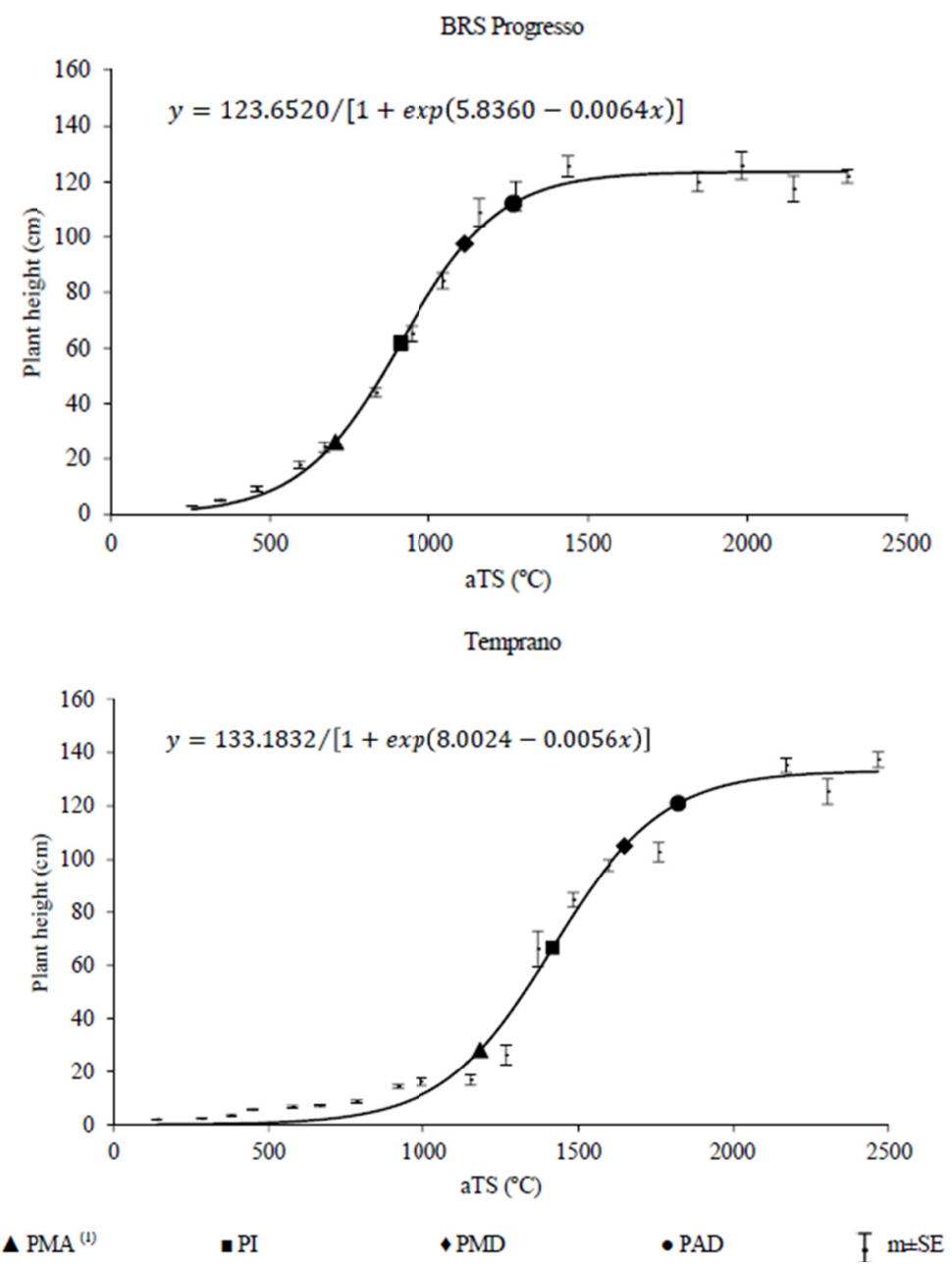

Figure 3. Graph of the Logistic model for plant height as a function of the accumulated thermal sum $\left(\mathrm{aTS}\right.$, in $\left.{ }^{\circ} \mathrm{C}\right)$ of the cultivars BRS Progresso (time 5) and Temprano (time 3 ) of rye (Secale cereale L.)

Note. ${ }^{(1)}$ Point of inflection (PI), point of maximum acceleration (PMA), point of maximum deceleration (PMD), point of asymptotic deceleration (PAD), mean \pm standard error $(\mathrm{m} \pm \mathrm{SE})$, estimated based on 10 rye plants, at each evaluation time of sowing times. 
In order to exemplify the growth of the crop, the equation $y=123.6520 /[1+\exp (5.8360-0.0064 x)]$ in the Logistic model was obtained for plant height, based on the accumulated thermal sum (aTS) of the BRS Progresso cultivar, during time 5. Taking for instance a notional number of $750{ }^{\circ} \mathrm{C}$ for the thermal sum, the estimated value for the plant height is $32.71 \mathrm{~cm}$, a value found between the point of maximum acceleration and the point of inflection. For this case, the crop procedures that enable the initial growth of the plant should have been executed. In the case growth is not satisfactory for the crop; the investigator should check for the reason for this crop pattern and then apply the proper crop management practices, obtaining therefore a crop with a promising pattern for soil cover or grain production. So, for the rye crop, in subsequent investigations, the option should be for the equation obtained in the present study, using a new thermal sum from the harvest and analyzing if the feature is similar condition for the sowing time and cultivar, in order to check if crop management might already be employed.

Growth models are important to choose the better time to introduce the crop, in order to obtain better quality plant agronomic features. The option for the Logistic model might be prioritized by the investigator to describe the height increase of the rye, as well as in Berger (1981), where the Logistic model was the most appropriate to describe the progress of plant diseases, but the chosen model should be the one that best meets the perspectives of the research, taking into account the sowing time. In practice, enables the investigator to choose the growth model according to the characteristics of the crop, considering the sowing time for each cultivar. The information generated in this study is valid for the BRS Progresso and Temprano in the studied environment and might serve as a reference for the crop in future investigations. For other genotypes and environments, other studies should be conducted.

\section{Conclusions}

The Gompertz and Logistic models describe successfully the plant height pattern in the BRS Progresso and Temprano rye cultivars at sowing time.

The model that best describes the growth of the BRS Progresso and Temprano rye cultivars regarding plant height is the Logistic model.

\section{Acknowledgements}

To the National Council for Scientific and Technological Development (CNPq-Processes 401045/2016-1 and 304652/2017-2) and the Coordination for the Improvement of Higher Education Personnel (Capes) and Foundation for Research Support of the State of Rio Grande do Sul (FAPERGS), for granting scholarships. Students who assisted in data collection.

\section{References}

Arnold, C. Y. (1960). Maximum-Minimum temperature as a basis for computing heat units. Proceedings of the American Society for Horticultural Science, 76, 682-692.

Bates, D. M., \& Watts, D. G. (1988). Nonlinear regression analysis and its applications. New York: John Wiley \& Sons. https://doi.org/10.1002/9780470316757

Bem, C. M., Cargnelutti Filho, A., Chaves, G. G., Kleinpaul, J. A., Pezzini, R. V., \& Lavezo, A. (2018). Gompertz and Logistic models to the productive traits of sunn hemp. Journal of Agricultural Science, 10, 225-238. https://doi.org/10.5539/jas.v10n1p225

Bem, C. M., Cargnelutti Filho, A., Facco, G., Schabarum, D. E., Silveira, D. L., Simões, F. M., \& Uliana, D. B. (2017). Growth models for morphological traits of sunn hemp. Semina: Ciências Agrárias, 38, 2933-2944. https://doi.org/10.5433/1679-0359.2017v38n5p2933

Berner, R. D. (1981). Comparison of the Gompertz and Logistic equations to describe plants diasease progress. Ecology and Epidemiology, 71, 716-719.

Bruckner, P. L., \& Raymer P. L. (1990). Factors influencing species and cultivar choice of smail grains for winter forage. Journal of Production Agriculture, 3, 349-355. https://doi.org/10.2134/jpa1990.0349

CONAB (Companhia Nacional de Abastecimento). (2017). Acompanhamento da safra brasileira de grãos-Safra 2017/18. CONAB, Brazil. Retrieved from http://www.conab.gov.br/OlalaCMS/uploads/arquivos/17_10_ 16_16_34_39_graos_outubro_2017.pdp

Deprá, M. S., Lopes, S. J., Noal, G., Reiniger, L. R. S., \& Cocco, D. T. (2016). Modelo logístico de crescimento de cultivares crioulas de milho e de progênies de meios-irmãos maternos em função da soma térmica. Ciência Rural, 46, 36-43. https://doi.org/10.1590/0103-8478cr20140897 
Doneda, A., Aita, C., Giacomini, S. J., Miola, E. C. C., Giacomini, D. A., Schirmann, J., \& Gonzatto, R. (2012). Fitomassa e decomposição de resíduos de plantas de cobertura puras e consorciadas. Revista Brasileira de Ciência do Solo, 36, 1714-1723. https://doi.org/10.1590/S0100-06832012000600005

Empresa Brasileira de Pesquisa Agropecuária. (2014). Sistemas de produção Embrapa. Cultivo do centeio, Embrapa. Retrieved from https://www.spo.cnptia.embrapa.br/conteudo?p_p_id=conteudoportlet_WAR_ sistemasdeproducaolf6_1galceportlet\&p $\_$_lifecycle $=0 \& p \_p \_s t a t e=$ normal $\& p \_p \_$mode $=v i e w \& p \_p \_c o l i i d$ $=$ column-1\&p_p_col_count $=1 \&$ p_r_p_-76293187_sistemaProducaoId $=3702 \&$ p_r_p_-996514994_topicoId $=3019$

Fernandes, T. J., Pereira, A. A., Muniz, J. A., \& Savian, T. V. (2014). Seleção de modelos não lineares para a descrição das curvas de crescimento do fruto do cafeeiro. Coffee Science, 9, 207-215.

Gilmore, E. C., \& Rogers, J. S. (1958). Heat units as a method of measuring maturity in corn. Agronomy Journal, 50, 611-615. https://doi.org/10.2134/agronj1958.00021962005000100014x

Held in, A. B., Buriol, G. A., \& Streck, N. A. (2009). O clima de Santa Maria. Ciência \& Ambiente, 38, 43-58.

Karadavut, U. (2009). Non-linear models for growth curves of triticale plants under irrigation conditions. Turkish Journal of Field Crops, 14, 105-110.

Large, E. C. (1954). Growth stages in cereals illustration of the Feeks scales. Plant Pathology, 4, 128-129. https://doi. org/10.1111/j.1365-3059.1954.tb00716.x

Lyra, G. B., Lyra, G. B., Rocha, A. E. Q., Teodoro, I., Ponciano, N. P., \& Santos, M. A. (2013). Produtividade e modelos de crescimento para o mamoeiro cultivar Golden. Revista Ciência Agrícola, 11, 1-12. https://doi.org/10.28998/rca.v11i1.736

Mangueira, R. A. F., Savian, T. V., Muniz, J. A., Sermarini, R. A., \& Crosariol Neto, J. (2016). O modelo Logístico considerando diferentes distribuições para os erros aplicado a dados de altura de milho. Revista Brasileira de Biometria, 34, 317-333.

Meinerz, G. R., Olivo, C. J., Viégas, J., No rnberg, J. L., Agnolin, C. A., Scheibler, R. B., ... Fontaneli, R. S. (2011). Silagem de cereais de inverno submetidos ao manejo de duplo propósito. Revista Brasileira de Zootecnia, 40, 2097-2104. https://doi.org/10.1590/S1516-35982011001000005

Mischan, M. M., \& Pinho, S. Z. (2014). Modelos não lineares: funções assintóticas de crescimento. São Paulo: Cultura Acadêmica.

Muianga, C. A, Muniz, J. A., Nascimento, M. S., Fernandes, T. J., \& Savian, T. V. (2016). Descrição da curva de crescimento de frutos do cajueiro por modelos não lineares. Revista Brasileira de Fruticultura, 38, 22-32. https://doi.org/10.1590/0100-2945-295/14

Muniz, J. A., Nascimento, M. S., \& Fernandes, T. J. (2017). Nonlinear models for description of cacao fruit growth with assumption violations. Revista Caatinga, 30, 250-257. https://doi.org/10.1590/1983-21252017 v30n128rc

Nelder, J. A. (1961). The fitting of a generalization of the logistic curve. Biometrics, 17, 89-110. https://doi.org/10.23 07/2527498

R Development Core Team. (2018). R: A language and environment for statistical computing. Vienna: $\mathrm{R}$ Foundation for Statistical Computing.

Ratkowsky, D. A. (1983). Nonlinear regression modeling. New York: Marcel Dekker.

Rosa, V. G. C., Moreira, M. A., Rudorff, B. F. T., \& Marcos Adami, M. (2010). Estimativa da produtividade de café com base em um modelo agrometeorológico espectral. Pesquisa Agropecuária Brasileira, 45, 1478-1488. https://doi.org/10.1590/S0100-204X2010001200020

Santos, H. G., Jacomine, P. K. T., Anjos, L. H. C., Oliveira, V. A., Oliveira, J. B., Coelho, M. R., ... Cunha, T. J. F. (2013). Sistema brasileiro de classificação de solos. Brasília: Embrapa.

Sorato, A. M. C., Prado, T. K. L., \& Morais, A. R. (2014). Análise do crescimento vegetal por meio de modelo não linear via regressão isotônica. Revista da Estatística, 3, 139-143.

Windsor, C. P. (1932). The Gompertz curve as a growth curve. Proceedings of the National Academy of Sciences of the United States of America, 18, 1-8. https://doi.org/10.1073/pnas.18.1.1 


\section{Copyrights}

Copyright for this article is retained by the author(s), with first publication rights granted to the journal.

This is an open-access article distributed under the terms and conditions of the Creative Commons Attribution license (http://creativecommons.org/licenses/by/4.0/). 